\title{
Risk factors associated with Toxoplasma gondii infection in free-range chickens in the semiarid region of Brazil
}

Fatores de riscos associados com a infecção de Toxoplasma gondii em galinhas de vida livre na região do semiárido do Brasil

Silvio Gomes de Sá1; Müller Ribeiro-Andrade ${ }^{1}$; Luana Thamires Rapôso Silva ${ }^{1}$; Orestes Luiz de Souza Neto ${ }^{1}$; Débora Costa Viegas Lima'; Camila de Moraes Pedrosa ${ }^{1}$; Mauro José Gonçalves Bezerra²; Rinaldo Aparecido Mota ${ }^{1 *}$

${ }^{1}$ Departamento de Medicina Veterinária, Universidade Federal Rural de Pernambuco - UFRPE, Recife, PE, Brasil

${ }^{2}$ Superintendência do Desenvolvimento do Nordeste - SUDENE, Recife, PE, Brasil

Received October 6, 2016

Accepted May 17, 2017

\begin{abstract}
This study aimed to investigate the frequency of anti-Toxoplasma gondii antibodies in serum from 629 chickens on 39 family farms in seven municipalities in the semiarid region, Pernambuco, Brazil, and to identify risk factors associated with T. gondii infection. The risk factors were studied in 421 samples from 29 farms. Anti-T. gondii antibodies were investigated by indirect fluorescent antibody test with a 1:16 cutoff. The frequency of positive chickens was $27.9 \%$ $(176 / 629)$ and $94.8 \%$ of the farms studied had chickens infected by T. gondii. Multivariate analysis showed variables significantly associated with anti-T. gondii antibodies in serum: slaughter of animals on the farm, reproductive disorders in sheep, consumption of fetal adnexa and placentas by chickens, presence of sheep in the property and birth of sheep the property. The results suggest that there is a complex relationship between general management practices for different animal species raised on the same farm and the prevalence of T. gondii infection in chickens. In addition, the results draw attention to the risk of human infection by $T$. gondii via consumption of infected chicken meat, because the farming conditions and the low human development indices observed in the region studied result in inappropriate meat preparation practices.
\end{abstract}

Keywords: Toxoplasmosis, chickens, family poultry, risk factors.

\section{Resumo}

Objetivou-se investigar a prevalência de anticorpos anti-Toxoplasma gondii em 629 soros de galinha em 39 propriedades da agricultura familiar em sete municípios de Pernambuco, Brasil e identificar os fatores de risco associados à infecção. Para a pesquisa de anticorpos anti- $T$. gondii empregou-se a reação de imunofluorescência indireta com ponto-de-corte 1:16. O estudo dos fatores de risco foi realizado em 29 propriedades, totalizando 421 amostras. A prevalência de aves positivas foi de $27,9 \%(176 / 629)$ e $94,8 \%$ das propriedades tinham galinhas infectadas por $T$. gondii. Na análise multivariada, obteve-se como variáveis significativas associadas com anticorpos anti-T. gondii a ocorrência de abate de animais na propriedade, relato de distúrbios reprodutivos em ovinos, ingestão de anexos fetais e placentas pelas galinhas, presença de ovinos na propriedade e nascimento de ovinos na propriedade. Os resultados sugerem relaçōes complexas entre o manejo das espécies animais criados nas propriedades e a prevalência da infecção nas galinhas. Em adicional, chama-se atenção para o risco de infecção humana por T. gondii via consumo de carne de galinha infectada, uma vez que as condiçôes de criação e os baixos índices de desenvolvimento observados na regiáo resultam em inapropriada preparação da carne para consumo.

Palavras-chave: Toxoplasmose, galinhas, criação familiar, fatores de risco.

*Corresponding author: Rinaldo Aparecido Mota. Departamento de Medicina

Veterinária, Universidade Federal Rural de Pernambuco - UFRPE, Rua Dom

Manoel de Medeiros, s/n, Dois Irmãos, CEP 52171-900, Recife, PE, Brasil.

e-mail: rinaldo.mota@hotmail.com 


\section{Introduction}

Toxoplasma gondii is found worldwide and can infect an exceptionally broad range of hosts such as humans, livestock, pets and wildlife. All felids are considered to be definitive hosts of T. gondii (MONTOYA \& LIESENFELD, 2004).

Chickens are one of the most important intermediate hosts in the epidemiology of toxoplasmosis because they are an efficient source of infection for cats and humans through consumption of undercooked infected chicken meat (DUBEY, 2010). Studies have showed that chickens are an important source of $T$. gondii infection for humans (DUBEY, 2010; TENTER et al., 2000). In addition, chickens are good indicators of environmental contamination by $T$. gondii oocysts because they feed from the soil and thus become exposed to oocysts (DUBEY, 2010; HILL \& DUBEY, 2013). Therefore, poultry is used as a sentinel in regions with high prevalence of T. gondii infection in humans (DUBEY et al., 2002).

In Brazil, studies have showed high prevalence of $T$. gondii infection in poultry in the southern region (GARCIA et al., 2000) and southeastern region (CASARTELLI-ALVES et al., 2012), thus suggesting that high environmental contamination is present, with a high risk of human and animal infection. However, few studies on occurrences of $T$. gondii infection in free-range chickens have been conducted, especially in the northeastern region of the country.

In this context, the present study aimed to estimate the frequency of anti-T. gondii antibodies in free-range chickens and to identify risk factors associated with infection by this protozoon on family farms in the semiarid region of Brazil.

\section{Material and Methods}

\section{Area of study and sampling}

A cross-sectional epidemiological study was conducted on family farms located in seven municipalities in the semiarid region of the state of Pernambuco, Brazil: Jupí, Lajedo, Paranatama, Itaíba, Iati, Sertânia and Tuparetama.

The sample size was calculated considering a population of 336,221 chickens in the state of Pernambuco (IBGE, 2010) and an expected prevalence of toxoplasmosis of $50 \%$. A prevalence of $50 \%$ was chosen to maximize the sample size, thereby ensuring a minimum $95 \%$ confidence interval (CI) with a statistical error of 5\% (THRUSFIELD, 2004). Therefore, according to the calculation, the minimum sample size to be analyzed was 384 animals. We collected blood serum samples from 629 chickens on 39 farms.

\section{Collection of blood samples}

The chickens were individually restrained and their general clinical condition was evaluated. Afterwards, approximately $2 \mathrm{ml}$ of blood was collected from adult birds of both sexes through puncture of the brachial vein. The blood samples were then centrifuged to obtain serum.

\section{Serological examination}

The serum samples were evaluated by an in house indirect fluorescent antibody test (in house IFAT) to detect any presence of anti-T. gondii antibodies, in accordance with the method proposed by Camargo (1974). A serum dilution of 1:16 was adopted as cut-off (MILLAR et al., 2012). Known positive and negative controls were included in all reactions. T. gondii tachyzoites (RH strain) were used as antigens in the slide preparation.

Sera were diluted in Phosphate Buffered Solution (PBS, $\mathrm{pH} 7.2)$ at room temperature and were placed in wells on slides and incubated at $37^{\circ} \mathrm{C}$ for 30 minutes in humid chamber. The slides were washed in PBS, three times during ten minutes, followed by an incubation $\left(37^{\circ} \mathrm{C}\right.$ for 30 minutes in humid chamber) with anti-chicken IgG antibody conjugated for fluorescein isothiocyanate (Sigma Chemical ${ }^{\circledR}$, USA), diluted 1:400 in PBS containing 0.05\% of Evans Blue (Sigma Chemical ${ }^{\circledR}$, USA). The slides were washed again, covered with buffered glycerin ( $\mathrm{pH}$ 8.0) and a cover slip and then examined under a fluorescent microscope (Nikon Eclipse; objective: 40x) by one trained person.

\section{Investigation of risk factors and statistical analysis}

To study risk factors associated with $T$. gondii infection, questionnaires with multiple choice questions relating to production and sanitary management of poultry and the epidemiology of toxoplasmosis were applied on 29 of the 39 farms on which blood samples were collected, totaling 421 samples. These farms were located in the municipalities of Jupi, Lajedo, Paranatama and Itaíba. The same person applied the questionnaires on all the farms. The number of farms was chosen according to convenience, but it fulfilled the minimum sample size that had previously been calculated.

The variables studied were: presence of cats on the property; occurrence of birth of cats on the property; presence of sheep in the property; birth of sheep in the property; intake of fetal adnexa, fetal fluids and placentas by chickens; slaughter of animals in the property; reproductive disorders (abortion, return to estrus, stillbirths) in sheep.

The variables of the questionnaires were evaluated by means of univariate analysis using Pearson's chi-square test or Fisher's exact test $(p<0.05)$, when necessary, adopting a 95\% confidence interval. The logistic regression model took the serological results (positive or negative) as the dependent variable for use in the multivariate analysis $(p<0.05)$. The statistical analyses were performed in the Epi Info 3.5.1 software (Centers for Disease Control and Prevention).

\section{Ethical aspects}

All procedures had previously been approved by the Ethics Committee for Animal Use (CEUA-UFAL; License no. 54/2014). 


\section{Results}

In the present study, $27.9 \%(176 / 629)$ of the blood samples from the chickens were positive for anti-T. gondii antibodies (CI: $24.5 \%$-31.7\%). Itaíba (46\%) and Lajedo (14.1\%) were the municipalities with the highest and lowest percentages of positive samples, respectively (Table 1). A total of $94.8 \%$ (37/39) of the farms had at least one positive animal. According to the univariate analysis, all seven variables were associated with $T$. gondii infection in chickens (Table 2).

Logistic regression (Table 2) confirmed the following variables as risk factors for $T$. gondii infection in poultry in the semiarid: slaughter of animals on the farm (OR 1.66); reproductive disorders in sheep (OR 2.29); intake of fetal adnexa, fetal fluids and placentas by chickens (OR 2.58); presence of sheep in the property (OR 1.96) and birth of sheep the property (OR 1.72).

\section{Discussion}

In our study, all the farms had similar social and economic characteristics and were categorized as family-based farms (UN-PNDU, 2013). On these farms, the average frequency of chickens positive for anti-T. gondii antibodies was $27.9 \%$, ranging from $14.1 \%$ to $46.0 \%$.

Itaíba presented the highest prevalence of chickens positive for T. gondii. The farms in this municipality belong to a rural

Table 1. Absolute and relative frequencies of free-range chickens exposure to T. gondii accessed by indirect immunofluorescence test (cutoff at dilution of 1:16).

\begin{tabular}{cccc}
\hline \multirow{2}{*}{ Municipalities } & \multirow{2}{*}{ Positive farms / Total farms } & \multicolumn{2}{c}{ Animals } \\
\cline { 3 - 4 } & $2 / 4$ & N total & Positives (\%) \\
\hline Jupi & $5 / 5$ & 62 & $12(19.4 \%)$ \\
Lajedo & $12 / 12$ & 64 & $9(14.1 \%)$ \\
Paranatama & $9 / 9$ & 208 & $49(23.6 \%)$ \\
Itaíba & $4 / 4$ & 100 & $46(46.0 \%)$ \\
Iatí & $1 / 1$ & 36 & $9(25.0 \%)$ \\
Sertânia & $4 / 4$ & 67 & $17(25.4 \%)$ \\
Tuparetama & $37 / 39$ & 92 & $34(37.0 \%)$ \\
Total & & 629 & $176(27.9 \%)$ \\
\hline
\end{tabular}

$\mathrm{N}$ - number.

Table 2. Univariate and multivariate analysis of risks factors associated with Toxoplasma gondii infection in free-range chicken from semiarid region, Brazil.

\begin{tabular}{|c|c|c|c|c|c|c|}
\hline \multirow{2}{*}{ Variables } & \multicolumn{3}{|c|}{ RIFI and Univariate analysis } & \multicolumn{3}{|c|}{ Logistic regression } \\
\hline & Positive $^{a}$ & Negative & p-value & $\mathbf{O R}^{\mathrm{b}}$ & p-value & C.I. $95 \%^{\mathrm{c}}$ \\
\hline \multicolumn{7}{|l|}{ Presence of cats on the property } \\
\hline Yes & $91(29.4 \%)$ & $219(70.6 \%)$ & \multirow{2}{*}{0.032} & \multirow{2}{*}{1.68} & \multirow{2}{*}{0.053} & \multirow{2}{*}{$0.99-2.84$} \\
\hline No & $22(19.8 \%)$ & $89(80.2 \%)$ & & & & \\
\hline \multicolumn{7}{|c|}{ Occurrence of birth of cats on the property } \\
\hline Yes & $32(34.8 \%)$ & $60(65.2 \%)$ & \multirow{2}{*}{0.036} & \multirow{2}{*}{1.63} & \multirow{2}{*}{0.053} & \multirow{2}{*}{$0.99-2.68$} \\
\hline No & $81(24.6 \%)$ & $248(75.4 \%)$ & & & & \\
\hline \multicolumn{7}{|c|}{ Presence of sheep in the property } \\
\hline Yes & $80(32.0 \%)$ & $170(68.0 \%)$ & \multirow{2}{*}{0.002} & \multirow{2}{*}{1.96} & \multirow{2}{*}{0.004} & \multirow{2}{*}{$1.23-3.12$} \\
\hline No & $33(19.3 \%)$ & $138(80.7 \%)$ & & & & \\
\hline \multicolumn{7}{|l|}{ Birth of sheep in the property } \\
\hline Yes & $58(33.1 \%)$ & $117(66.9 \%)$ & \multirow{2}{*}{0.009} & \multirow{2}{*}{1.72} & \multirow{2}{*}{0.014} & \multirow{2}{*}{$1.11-2.65$} \\
\hline No & $55(22.4 \%)$ & $191(77.6 \%)$ & & & & \\
\hline \multicolumn{7}{|c|}{ Slaughter of animals in the property } \\
\hline Yes & 77 (30.8\%) & $173(69.2 \%)$ & \multirow{2}{*}{0.017} & \multirow{2}{*}{1.66} & \multirow{2}{*}{0.027} & \multirow{2}{*}{$1.05-2.63$} \\
\hline No & $36(21.1 \%)$ & $135(78.9 \%)$ & & & & \\
\hline \multicolumn{7}{|c|}{$\begin{array}{l}\text { Reproductive disorders (abortion, return to } \\
\text { estrus, stillbirths) in sheep }\end{array}$} \\
\hline Yes & $27(42.2 \%)$ & $37(57.8 \%)$ & \multirow{2}{*}{0.002} & \multirow{2}{*}{2.29} & \multirow{2}{*}{0.003} & \multirow{2}{*}{$1.32-3.99$} \\
\hline No & $86(24.1 \%)$ & $271(75.9 \%)$ & & & & \\
\hline \multicolumn{7}{|c|}{$\begin{array}{l}\text { Intake of fetal adnexa. fetal fluids and } \\
\text { placentas by chickens }\end{array}$} \\
\hline Yes & $18(46.2 \%)$ & $21(53.8 \%)$ & 0.005 & 2.58 & 0.005 & $1.32-5.06$ \\
\hline No & $95(24.9 \%)$ & $287(75.1 \%)$ & & 2.50 & 0.005 & $1.52-5.00$ \\
\hline
\end{tabular}

${ }^{\mathrm{a}}$ Absolute frequency (Relative frequency); ${ }^{\mathrm{b}}$ Odds ratio; ${ }^{\mathrm{c}}$ Confidence interval. 
settlement project in which the houses are in a village system and are approximately 25 meters apart from each other. The close proximity of the houses and cohabitation of chickens of different farmers in the same contaminated environment may explain the high frequency of positive chickens found in this municipality. The other farms evaluated in the present study were hundreds of meters apart from each other and had lower prevalence of chickens positive for anti- $T$. gondii antibodies. Only the municipality of Jupí had farms (two) with all chickens negative for anti-T. gondii antibodies. In these two farms, there is no breeding other domestic animals that could be protective factor for chickens because lack probable sources of infection.

Studies on the prevalence of anti-T. gondii antibodies in free-range chickens have been conducted worldwide using different techniques. In this regard, Casartelli-Alves et al. (2012) observed that most studies conducted in Brazil on chickens on family farms aimed to genetically characterize $T$. gondii isolates instead of determining the prevalence of this protozoon. In Brazil, the frequency of positive chickens has ranged from $10.3 \%$ (GARCIA et al., 2000) to $80 \%$ in different studies (COSTA et al., 2012).

The presence of cats eliminating oocysts may contaminate the soil from which the chickens feed, thus increasing the frequency of positive chickens. Overall, the present study no found significant association between the presence of cats on the farms and the frequency of positive chickens. This result is similar to that of Marques et al. (2009), who also did not detect any statistical association between the presence of cats and $T$. gondii infection in chicken, even after observing that $57 \%(8 / 14)$ of the cats were positive for anti-T. gondii antibodies. On the other hand, the participation of cats in environmental contamination by oocysts is well known (MONTOYA \& LIESENFELD, 2004) and Millar et al. (2012) described an association between high prevalence of positive chickens and the presence of cats. According to Beltrame et al. (2012), variations in the seropositivity of chickens for T. gondii may be related to the presence of cats on farms.

However, other sources of infection should not be ruled out. Reproductive disorders in sheep were considered a risk factor for infection of chickens ( $p$ 0.003; OR 2.29), in additional, observed that chickens had access to and consumed fetal adnexa, fetal fluids and placentas of sheep ( $\mathrm{p} 0.005$; OR 2.58) suggesting that there is some relationship between these two species in the transmission of toxoplasmosis. It is known that $T$. gondii cysts may be present in placentas and fetal adnexa from aborted sheep fetuses (BUXTON, 1998; OWEN et al., 1998).

Consumption of undercooked or raw meat from free-range chickens can be a source of $T$. gondii infection for humans and other animals because chickens can host viable $T$. gondii cysts in their tissues (DUBEY, 2010). Moreover, lack of hygiene during handling of poultry meat may contribute towards human infection and inadequate disposal of viscera from infected chickens can facilitate transmission of $T$. gondii to other hosts such as cats. On the farms studied here, we observed that dogs, cats, pigs and chickens routinely consumed viscera from chickens. The multivariate analysis showed that slaughter of animals on the farm (OR 1.66) is a risk factor for T. gondii infection in chickens. This result corroborates the findings of Kaneto et al. (1997), who showed that T. gondii cysts were present in viscera from experimentally infected chicken, such as the intestines and proventriculus, which are organs disposed of in the environment after chickens are slaughtered on the farms studied and could be source of infection to definitive host.

This is the first study conducted in the semiarid region of the state of Pernambuco, Brazil, that focused on the frequency of anti- $T$. gondii antibodies in chickens. The results suggest that there is a complex relationship between general management practices for different animal species raised (sheep) on the same farm and the prevalence of $T$. gondii infection in chickens. In addition, the results draw attention to the risk of human infection $T$. gondii by consumption and manipulation of infected chicken meat. It is also important to perform a serological survey in humans in this region that presents low human development indice to verify if there is relation between the positivity to $T$. gondii and the manipulation or consumption of chickens meat infected with $T$. gondii.

\section{Conflict of interest statement}

There was no conflict of interest for any of the authors involved in this study.

\section{References}

Beltrame MAV, Pena HFJ, Ton NC, Lino AJB, Gennari SM, Dubey JP, et al. Seroprevalence and isolation of Toxoplasma gondii from freerange chickens from Espírito Santo state, southeastern Brazil. Vet Parasitol 2012; 188(3-4): 225-230. PMid:22541793. http://dx.doi.org/10.1016/j. vetpar.2012.03.053.

Buxton D. Protozoan infections (Toxoplasma gondii, Neospora caninum and Sarcocystis spp.) in sheep and goats: recent advances. Vet Res 1998; 29(3-4): 289-310. PMid:9689743.

Camargo ME. Introdução às técnicas de Imunofluorescência. Rev Bras Patol Clin 1974; 10(3): 143-169.

Casartelli-Alves L, Ferreira LC, Vicente RT, Millar PR, Oliveira RVC, Amendoeira MRR, et al. Prevalência da infecção por Toxoplasma gondii em galinhas criadas extensivamente em Rio Bonito, Rio de Janeiro. Arq Bras Med VetZootec 2012; 64(5): 1398-1401. http://dx.doi.org/10.1590/ S0102-09352012000500042.

Costa DGC, Marvulo MFV, Silva JSA, Santana SC, Magalhães FJR, Lima CDF Fo, et al. Seroprevalence of Toxoplasma gondii in domestic and wild animals from the Fernando de Noronha, Brazil. J Parasitol 2012 98(3): 679-680. PMid:22150091. http://dx.doi.org/10.1645/GE-2910.1.

Dubey JP. Toxoplasma gondii infections in chickens (Gallus domesticus): Prevalence, clinical disease, diagnosis and public health significance. Zoonoses Public Health 2010; 57(1): 60-73. PMid:19744305. http:// dx.doi.org/10.1111/j.1863-2378.2009.01274.x.

Dubey JP, Graham DH, Blackston CR, Lehmann T, Gennari SM, Ragozo AMA, et al. Biological and genetic characterisation of Toxoplasma gondii isolates from chickens (Gallus domesticus) from São Paulo, Brazil: Unexpected findings. Int J Parasitol 2002; 32(1): 99-105. PMid:11796127. http://dx.doi.org/10.1016/S0020-7519(01)00364-2.

Garcia JL, Navarro IT, Ogawa L, Marana ERM. Soroprevalência do Toxoplasma gondii em galinhas (Gallus gallus domesticus) de criaçóes domésticas, oriundas de propriedades rurais do Norte do Paraná, Brasil. Cienc Rural 2000; 30(1): 123-127. http://dx.doi.org/10.1590/S010384782000000100020 . 
Hill DE, Dubey JP. Toxoplasma gondii prevalence in farm animals in the United States. Int J Parasitol 2013; 43(2): 107-113. PMid:23201235. http://dx.doi.org/10.1016/j.ijpara.2012.09.012.

Instituto Brasileiro de Geografia e Estatística - IBGE. Censo Agropecuário [online]. 2010 [cited 2015 Nov 20]. Available from: http://www.ibge. gov.br/home/estatistica/economia/ppm/2010/

Kaneto CN, Costa AJ, Paulillo AC, Moraes FR, Murakami TO, Meireles MV. Experimental toxoplasmosis in broiler chicks. Vet Parasitol 1997; 69(3-4): 203-210. PMid:9195730. http://dx.doi.org/10.1016/S03044017(96)01126-0.

Marques JM, Isbrecht FB, Lucas TM, Guerra IMP, Dalmolin A, Silva $\mathrm{RC}$, et al. Detecção de anticorpos anti-Toxoplasma gondii em animais de uma comunidade rural do Mato Grosso do Sul, Brasil. Semina: Ciênc Agrar 2009; 30(4): 889-898.

Millar PR, Alves FMX, Teixeira VQ, Vicente RT, Menezes EM, Sobreiro LG, et al. Occurrence of infection with Toxoplasma gondii and factors associated with transmission in broiler chickens and laying hens in different raising systems. Pesqui Vet Bras 2012; 32(3): 231-236. http:// dx.doi.org/10.1590/S0100-736X2012000300009.

Montoya JG, Liesenfeld O. Toxoplasmosis. Lancet 2004; 363(9425): 1965-1976. PMid:15194258. http://dx.doi.org/10.1016/S01406736(04)16412-X.

Owen MR, Clarkson MJ, Trees AJ. Diagnosis of toxoplasma abortion in ewes by polymerase chain reaction. Vet Rec 1998; 142(17): 445-448. PMid:9602512. http://dx.doi.org/10.1136/vr.142.17.445.

Tenter AM, Heckeroth AR, Weiss LM. Toxoplasma gondii: from animals to humans. Int J Parasitol 2000; 30(12-13): 1217-1258. PMid:11113252. http://dx.doi.org/10.1016/S0020-7519(00)00124-7.

The United Nations Development Programme - UN-PNDU. Decreasing ranking HDI of municipalities in Brazil: atlas of Human Development [online]. 2013 [cited 2015 Dec 12]. Available from: http://www.pnud. org.br/atlas/ranking/ranking-idhm-municipios-2010.aspx.

Thrusfield MV. Epidemiologia veterinária. 2. ed. São Paulo: Roca; 2004. 